\title{
Development of a Laser-Electron-Interaction Region for Compact High Repetition-Rate Mono-Energetic Laser Based Gamma Sources
}

\author{
Cooperative Research and Development Agreement \\ Final Report
}

CRADA Number: FRA-2015-0289

Fermilab Technical Contact: Dr. Jinhao Ruan

Summary Report

22 October 2020 


\section{NOTICE}

This report was prepared as an account of work sponsored by an agency of the United States government. Neither the United States government nor any agency thereof, nor any of their employees, makes any warranty, express or implied, or assumes any legal liability or responsibility for the accuracy, completeness, or usefulness of any information, apparatus, product, or process disclosed, or represents that its use would not infringe privately owned rights. Reference herein to any specific commercial product, process, or service by trade name, trademark, manufacturer, or otherwise does not necessarily constitute or imply its endorsement, recommendation, or favoring by the United States government or any agency thereof. The views and opinions of authors expressed herein do not necessarily state or reflect those of the United States government or any agency thereof.

Available electronically at http://www.osti.gov/

Available for a processing fee to U.S. Department of Energy and its contractors, in paper, from:

U.S. Department of Energy

Office of Scientific and Technical Information

P.O. Box 62

Oak Ridge, TN 37831-0062

phone: 865.576.8401

fax: 865.576 .5728

email: mailto:reports@osti.gov

Available for sale to the public, in paper, from:

U.S. Department of Commerce

National Technical Information Service

5301 Shawnee Rd

Alexandria, VA 22312

phone: 800.553 .6847 or $703-605-6000$

fax: 703.605.6900

email: orders@ntis.gov

online ordering: http://www.ntis.gov/ 
In accordance with Requirements set forth in Article XII of the CRADA document, this document is the final CRADA report, including a list of Subject Inventions, to be forwarded to the Office of Science and Technical Information as part of the commitment to the public to demonstrate results of federally funded research.

CRADA number: $\quad$ FRA-2015-0289

CRADA Title: $\quad$ Development of a Laser-Electron-Interaction region for Compact High-Repetition-Rate Mono-Energetic Laser-Based Gamma Sources

Parties to the Agreement: Northern Illinois University and Fermi Research Alliance, LLC Sponsoring DOE Program Office(s): Office of Science - High Energy Physics

DOE Funding Commitment Table:

\begin{tabular}{|c|c|c|c|c|c|c|c|c|c|c|}
\hline & \multicolumn{2}{|c|}{ Year 1} & \multicolumn{2}{|c|}{ Year 2} & \multicolumn{2}{|c|}{ Year 3} & \multicolumn{2}{|c|}{ Year 4} & \multicolumn{2}{|c|}{ Year 5} \\
\hline $\begin{array}{l}\text { Funding } \\
\text { Type }\end{array}$ & $\begin{array}{c}\text { Funds- } \\
\text { in }\end{array}$ & $\begin{array}{l}{ }^{*} \text { In- } \\
\text { kind }\end{array}$ & $\begin{array}{c}\text { Funds- } \\
\text { in }\end{array}$ & $\begin{array}{l}{ }^{*} \text { In- } \\
\text { kind }\end{array}$ & $\begin{array}{c}\text { Funds- } \\
\text { in }\end{array}$ & $\begin{array}{l}{ }^{*} \text { In- } \\
\text { kind }\end{array}$ & $\begin{array}{c}\text { Funds- } \\
\text { in }\end{array}$ & $\begin{array}{l}{ }^{*} \text { In- } \\
\text { kind }\end{array}$ & $\begin{array}{c}\text { Funds- } \\
\text { in }\end{array}$ & $\begin{array}{l}{ }^{*} \text { In- } \\
\text { kind }\end{array}$ \\
\hline $\begin{array}{l}\text { Dept. of } \\
\text { Energy }\end{array}$ & \multicolumn{2}{|c|}{ Note 1} & \multicolumn{2}{|c|}{ Note 1} & \multicolumn{2}{|c|}{ Note 1} & \multicolumn{2}{|c|}{ Note 2} & \multicolumn{2}{|c|}{ Note 2} \\
\hline Totals & \multicolumn{2}{|c|}{ N/A } & \multicolumn{2}{|c|}{$\mathrm{N} / \mathrm{A}$} & \multicolumn{2}{|c|}{ N/A } & \multicolumn{2}{|c|}{ N/A } & \multicolumn{2}{|c|}{$\mathrm{N} / \mathrm{A}$} \\
\hline
\end{tabular}

Note 1: The FAST facility is a research accelerator that is available on a limited basis to qualified researchers who agree to publish results in accordance with their funding agreements. DOE in-kind contributions related to the ongoing operation of the FAST facility cannot be easily calculated or tracked at the individual project level.

Note 2: The program was cancelled by NIU in Year 4 of the project. There was no DOE in-kind funding expended in Year 4 or Year 5 of the CRADA as a result of this cancellation.

\section{Abstract of CRADA work:}

Inverse-Compton scattering (ICS) is a well-established technique capable of producing monochromatic radiation over a large range of the electromagnetic spectrum. Most recently, ICS has attracted attention, owing to its compactness and possible coupling with novel acceleration methods to yield compact $\mathrm{X}$ - and $\boldsymbol{\gamma}$-ray sources.

Under this award, we carried out a systematic optimization of the ICS and demonstrate via numerical simulation that combining ICS with a conventional superconducting linac could produce Watt-level average-power $\boldsymbol{\gamma}$ rays with high spectral brightness. The study is performed with idealized laser and electron-beam distributions and confirmed with the realistic 
distributions simulated from start-to-end numerical modeling of the electron accelerator. The studies led to the design and engineering design of an ICS interaction point for the FAST facility along with some beam measurement. Due to the cancellation of the program in Year 3 long with delay in the commissioning of the FAST facility, we were not able to demonstrate the generation of $\boldsymbol{\gamma}$ rays, we, however, procured some of the hardware, installed some of the required infrastructures and plan to eventually generate $\boldsymbol{\gamma}$ ray pending future interest on the topics and availability of funding.

\section{Summary of Research Results:}

In general, the research outcome did not realize its full potential as the five-year grant was terminated after Year 3 due to a change in programmatic at DNDO.

The work done at the FAST facility focused on preparing the electron beam parameters and working on an optical transport line capable of transporting part of the laser beam up to the planned interaction point (where the laser and electron beam collide "head-on" to produce the $\boldsymbol{\gamma}$ rays via inverse Compton scattering. The optical system was designed in collaboration with Fermilab and some of the elements procured and/or built using the Fermilab machine shop. Likewise, the electron beam parameters were characterized in parallel to the FASTcommissioning activities and the $300 \mathrm{MeV}$ beam was sent close to the location of the interaction region. Finally, the interaction region was designed in collaboration with Fermilab staff. The system design and procured under this research are expected to find application in other experiments in the near future.

\section{Related Reports, Publications, and Presentations:}

- A high-flux $\boldsymbol{\gamma}$ - ray source coupling inverse Compton Scattering to a pulsed superconducting linear accelerator, D. Mihalcea, T. Campese, A. Fetterman, A. Khizhanok, A. Murokh, P. Piot, J. Ruan, and M. Urfer, manuscript in preparation (2020).

- Coherent Stacking Scheme for Inverse-Compton Scattering at MHz Repetition Rates, D. Mihalcea, P. Piot, J. Ruan, T.J. Campese, A.Y. Murokh, Proceedings of the 2018 International Particle Accelerator Conference (IPAC'18), Vancouver, BC, Canada, April 29 - May 4, 2018, paper THPMF025.

- High Spectral Density Compton Back-Scattered Gamma-Ray Sources at Fermilab, D. Mihalcea,

- B. Jacobson, A. Khizhanok, A. Murokh, P. Piot, Proceedings, 38th International Free Electron Laser Conference, FEL2017 DOI: 10.18429/JACoW-FEL2017-MOP053

- Development of a Watt-level Gamma-Ray Source based on High-Repetition-Rate Inverse Compton Scattering, D. Mihalcea, A. Murokh, P. Piot, J. Ruan, Nucl. Instrum. Meth B 402 212 (2017); doi: 10.1016/j.nimb.2017.03.140

- High Brightness Gamma-Ray Production at Fermilab FAST Facility, D. Mihalcea, B.T. Jacobson, A.Y. Murokh, P. Piot, J. Ruan, Proceedings of the 17th Advanced Accelerator 
Concept Workshop (AAC16), National Arbor, MD, USA, July 31st - August 5th, 2016, AIP Conference Proceedings 1812, 100002 (2017); https://doi.org/10.1063/1.4975900 (2016).

- Design of a Gamma-Ray Source Based on Inverse Compton Scattering at the Fast Superconducting Linac, D. Mihalcea, B.T. Jacobson, A.Y. Murokh, P. Piot, J. Ruan

- Proceedings of the 2016 International Linear Accelerator Conference (LINAC'16), EastLansing, MI, USA, 25-30 September 2016, DOI: 10.18429/JACoW-LINAC2016-TUPLR015 (2016).

Subject Inventions listing:

$\mathrm{N} / \mathrm{A}$

Report Date: 22 October 2020

Technical Contact at Fermilab: Dr. Jinhao Ruan

Partner POC Name and Email Address: Dr. Philippe Piot, piot@nicadd.niu.edu

This document contains NO confidential, protectable or proprietary information. 